\title{
Influence of breed on selected quality parameters of fresh goat meat
}

\author{
Snežana Ivanović ${ }^{1}$, Marija Pavlović ${ }^{1}$, Ivan Pavlović ${ }^{1}$, Aleksandra Tasić ${ }^{1}$, Jelena Janjiće ${ }^{2}$, and \\ Milan Ž. Baltić ${ }^{2}$ \\ ${ }^{1}$ Scientific Veterinary Institute of Serbia, Belgrade, 11000, Serbia \\ ${ }^{2}$ Faculty of Veterinary Medicine, University of Belgrade, Belgrade, 11000, Serbia
}

Correspondence: Snežana Ivanović (snezaivanovic57@gmail.com)

Received: 27 December 2019 - Revised: 16 April 2020 - Accepted: 12 June 2020 - Published: 14 July 2020

\begin{abstract}
The potential of goats to produce a high-quality meat is mainly reflected in their healthy fats, low calorie intramuscular fats, saturated fats, and, especially, their high ratios of unsaturated (UFA) and saturated (SFA) fatty acids, as well as hypocholesterolemic and hypercholesterolemic fatty acids. The aim of this study was to collect and compare meat quality parameters for domestic Balkan, Alpine and Saanen goats of the same age. Samples for all tests were taken from musculus gluteus superficialis. Chemical composition, $\mathrm{pH}$ value, fatty acid composition, content of volatile compounds, color and overall sensory quality (appearance, texture and smell) were determined. In chemical composition, moisture, fat, protein and ash varied significantly between each of the examined groups as opposed to $\mathrm{pH}$ values. Furthermore, among all the examined groups a significant difference was found for fatty acids and volatile compounds. Determined ratio of polyunsaturated fatty acids (PUFAs) to SFAs was $0.089,0.085$ and 0.071 for Balkan, Alpine and Saanen goat meats, respectively. Regarding that ratio, Saanen goat meat had the most favorable characteristics. Saanen goat meat showed the highest nutritional value. On the other hand, Balkan goat meat had the lowest intramuscular fat content. Measurements of the meat color from all three groups, as well as overall acceptability, showed significant differences between breeds. Obtained results point to the impact of breed on chemical composition and fatty acid profile of goat meat.
\end{abstract}

1

\section{Introduction}

In most countries, goats are the most spread ruminants of all domesticated ruminants due to their ability to adapt themselves which is especially expressed in difficult climatic conditions (Tefiel et al., 2018). The number of goats in the world was, in 2018, over a billion - 1046146964 (FAO, 2020) and in Europe there were 10433360 goats in 2019 (Eurostat, 2020). According to the Statistical Office of the Republic of Serbia (2019) in 2018, 195934 goats were reared in Serbia. The local goat population is mainly located in small rural areas, and they are generally reared in very small herds on single-family farms.

Although the number of goats in Serbia is constantly increasing (Žujović et al., 2009), goat meat is not traditionally consumed due to consumers' habit, and the meat cannot easily be found in retail stores.
Of the total number of goats registered in Serbia, the Alpine goat is the most dominant accounting for $87 \%$ of animals, followed by two local breeds: Balkan goats and Serbian White goats. Alpine goats are widespread throughout different regions of Serbia, as well as globally. The domestic Balkan goat is a primitive goat breed in Serbia. This is the indigenous goat breed that is listed in the national program for the protection and conservation of animal genetic resources. The pure bred Saanen goat, an ideal white dairy goat breed with high productivity, is mainly raised for milk production (Žujović et al., 2009, 2011).

Producers and consumers are showing increasing interest in goat meat since the animals have very small amounts of subcutaneous and intramuscular fat. Compared to sheep of a similar age, their carcasses are very lean (Stanišić et al., 2012). Nutritionally, goat meat is an important source of high-quality protein, healthy fats, low calorie intramuscu- 
lar fats, saturated fats and sodium. In addition, goat meat has high levels of iron, potassium and essential amino acids (McMillin and Brock, 2005; Givens et al., 2006; Lee et al., 2008; Horcada et al. 2012).

Fatty acids play an important role in human nutrition. All unsaturated fatty acids (UFAs) plus stearic fatty acids (UFAs + C18:0) are categorized as desirable fatty acids (DFAs), while all saturated fatty acids (SFAs) minus stearic fatty acids (SFAs - C18:0) are considered hypercholesterolemic or undesirable fatty acids (OFAs) (Solaiman et al., 2011). Unsaturated fatty acids (UFAs) have a hypocholesterolemic effect. However, not all SFAs have the same effects. Lauric (C12:0), myristic (C14:0) and palmitic (C16:0) acids are hypercholesterolemic, while saturated stearic (C18:0) acid does not increase blood cholesterol levels and is considered neutral (Banskalieva et al., 2000). In general, the high ratio of UFA/SFA and DFA / OFA in goat meat demonstrates the potential of goats to produce meat with high nutritional value (Brzostovski et al., 2008; Pena et al., 2009). Meat quality can be influenced by several factors such as slaughter age, breed, genotype, gender, diet and treatment during slaughter (Costa et al., 2008; Toplu et al., 2013; Čobanović et al., 2019). On the other hand, appearance, tenderness, taste and juiciness are important categories that affect the consumers' acceptability of goat meat (Madruga et al., 2008; Silva et al., 2011).

The aim of this study was to examine some physical, chemical and sensory characteristics in goat meat of different breeds.

\section{Materials and methods}

\subsection{Ethics statement}

All the experimental procedures and animal handling used in this study were in accordance with guidelines of the European Community (Directive86/609/EEC) and guidelines of the Ethics Committee of the Faculty of Veterinary Medicine, University of Belgrade, Serbia.

\subsection{Animals and sampling}

Balkan goats, Alpine goats and Saanen goats were studied: 120 individuals in total, 40 of each breed. All goats were raised during the same period and were about 4 years old at slaughter, which occurred during August-September. All goats were selected from private farms in the mountain region Stara Planina (height 1000-1500 m a.s.1.), Serbia. Animals had ad libitum access to water. The goats' winter diets consisted of hay collected from natural pastures $\left(3.5 \mathrm{~kg} \mathrm{~d}^{-1}\right.$ per animal) and concentrate $\left(0.25 \mathrm{~kg} \mathrm{~d}^{-1}\right.$ per animal). In summer, the goats were pastured and fed with concentrate $\left(0.25 \mathrm{~kg} \mathrm{~d}^{-1}\right)$. The winter hay and summer pasture originated from natural meadows in the region. Plants were determined and their names harmonized with the nomen- clature according to the published literature (Lakusić and Cetković, 2007; Stevanović, 2012). Botanical composition of hay and pasture was as follows: Arrhenatheretum elatioris, Festuco-Chrysopogonetum, Danthonietum calycinae, Medicago falcate-Festucetum rubrae, Trifolio campestreAgrostietum vulgaris, Festuco vallesiacae and Agrostieutum vulgaris with the predomination of family Poaceae (Arrhenatherum elatius, Dactylis glomerata, Festuca pratensis Huds. $i$ Lolium perenne and family Fabaceae (Lotus corniculatus, Trifolium repens, Lathyrus pratensis, Trifolium montanum, Trifolium campestre). The concentrate feedstuff was composed of maize meal, wheat bran, sodium chloride and premix. This latter consisted of vitamins - A, D3, E, K3, C, B1, B2, B12, Niacin and Ca-pantothenate - and minerals - Fe, $\mathrm{Cu}, \mathrm{Mn}, \mathrm{Zn}, \mathrm{J}, \mathrm{Se}, \mathrm{Co}$ and $\mathrm{Mg}$. Complete feed mixture was formulated to meet or exceed the requirements set by the $\mathrm{Na}-$ tional Research Council (2007).

Preslaughter live weights of goats were recorded, and the animals were slaughtered in 3 consecutive days in the slaughterhouse at the Institute for Animal Husbandry, Belgrade, using captive-bolt stunning followed by the cutting of the carotid arteries and jugular veins. Carcasses were processed using standard industrial procedures and cooled at $4{ }^{\circ} \mathrm{C}$ for $48 \mathrm{~h}$. The 120 samples of goat meat - musculus gluteus superficialis - were collected during the trial. Individual muscle samples served as experimental units for analyses; hence, 40 samples for each examined breed were included in the study.

\subsection{Chemical composition of meat}

Within $48 \mathrm{~h}$ of slaughter, muscles were excised from the carcasses and packed into the polyethylene bags to protect the meat against drying. After packing and before analysis, meat samples were stored at $-20^{\circ} \mathrm{C}$. All analyses were conducted within 1 month of packing. Meat samples were thawed before examination at refrigerator temperature $\left(+2 \pm 2{ }^{\circ} \mathrm{C}\right)$. After defrosting and before analysis, samples were weighed to around $110 \mathrm{~g}$, and the thickness of the samples was $15 \mathrm{~mm}$.

The proximal composition, $\mathrm{pH}$, fatty acid content, volatile compound content, color and sensory acceptability were determined in the $m$. gluteus superficialis. Moisture content was determined by ISO 1442 (1998), fat content by ISO 1433 (1992) and ash content by ISO 936 (1999). The protein content was calculated from the nitrogen content multiplied by 6.25 using ISO 937 (1992), and $\mathrm{pH}$ was determined by ISO 2917 (2004).

\subsection{Fatty acids}

The AOAC 996.06 (2001) method was applied to the lipid extraction from the tissue. After the lipid hydrolysis, the fatty acids were esterified to methyl esters, evaporated to dryness in a stream of nitrogen and stored at $-18^{\circ} \mathrm{C}$. An analysis of fatty acid methyl esters (FAMEs) was performed by an inter- 
nal standard method using a gas chromatograph (GC6890N, Agilent Tech., USA) with column DB-23 $(60 \mathrm{~m} \times 0.25 \mathrm{~mm}$ ID, $0.15 \mu \mathrm{m})$ and peak areas and retention times were compared with a standard mix of FAME 37 (Supelco, USA). The conditions of the analyses are as follows: detector temperature $-250^{\circ} \mathrm{C}$; injector temperature $-225^{\circ} \mathrm{C}$; column temperature $-200^{\circ} \mathrm{C}$; carrier gas - helium; and carrier gas flow rate $-50 \mathrm{~mL} \mathrm{~min}^{-1}$. Obtained data for the composition of fatty acids were expressed in percentages by weight of the identified total fatty acids.

\subsection{Volatile compounds}

Volatile compound analyses were conducted using the extraction procedure from Likens-Nickerson (1964) followed by gas chromatography-mass spectrometry (GCMS) according to ISO 15303 (2001) using an GCMS-QP2010 Ultra (EIMS, electron ionization mass spectrometry; electron energy $-70 \mathrm{eV}$, scan range - 30-350 amu and scan rate 3.99 scans s $^{-1}$ ) with a SUPELCOWAX ${ }^{\circledR} 10$ Capillary GC Column $(30 \mathrm{~m} \times 0.25 \mathrm{~mm}$ ID, particle size $0.25 \mu \mathrm{m})$. The carrier gas was helium with a flow rate of $1 \mathrm{~mL} \mathrm{~min}^{-1}$, and the injection temperature was $200^{\circ} \mathrm{C}$. The oven temperature was programmed to initially hold for $10 \mathrm{~min}$ at $40^{\circ} \mathrm{C}$ and then to heat from 40 to $120^{\circ} \mathrm{C}$ at a rate of $3{ }^{\circ} \mathrm{C} \mathrm{min}^{-1}$ and subsequently at a rate of $10^{\circ} \mathrm{Cmin}^{-1}$ from 120 to $250^{\circ} \mathrm{C}$, at which point it was held for another $5 \mathrm{~min}$. Identification of the peaks was based on a comparison of their mass spectra with the spectra of the WILEY library and, in some additional cases, on a comparison of their retention times with those of standard compounds.

\subsection{Color}

Meat samples were bloomed for $30 \mathrm{~min}$ before the color measurement. CIE L*a*b* (CIE, 1986) color coordinates of meat were determined using a Minolta CR 400 Chroma Meter (Minolta Co. Ltd., Osaka, Japan) in D-65 lighting with a standard angle of $2^{\circ}$ of shelter and an $8 \mathrm{~mm}$ aperture measuring head. CIE $\mathrm{L}^{*} \mathrm{a} \mathrm{b}^{*}$ measurements are reported as mean values: $\mathrm{L}^{*}$ (lightness), $\mathrm{a}^{*}$ (redness) and $\mathrm{b}^{*}$ (yellowness).

\subsection{Sensory analysis}

Sensory analyses were carried out in the sensory laboratory equipped with individual booths. Each booth is made up of three walls on each side in order to prevent panelists influencing each other. All booths were provided with florescent lights to mask color differences between the samples. Sensory tests were performed at room temperature $\left(22-24^{\circ} \mathrm{C}\right)$. After a cooling period $\left(\right.$ at $\left.4{ }^{\circ} \mathrm{C}\right)$ of $24 \mathrm{~h}$, all tested samples were marked by random three-digit numbers. All meat samples were subjected to equal heat treatment in an electric oven at $170^{\circ} \mathrm{C}$ until a constant internal temperature of $80^{\circ} \mathrm{C}$ was reached. The meat samples were cut to an approximate size of $2.5 \mathrm{~cm} \times 2.5 \mathrm{~cm} \times 2.5 \mathrm{~cm}$. The samples were served individually to each panelist, in plastic bowls, at an internal meat temperature of $60 \pm 5{ }^{\circ} \mathrm{C}$ immediately after heat treatment. Tap water was provided to rinse the palate between samples.

The order of presentation of the samples was randomized for 20 trained panelists. The selection of panelists was conducted according to ISO standards (ISO 8586, 2012, 2015).

Overall acceptability was evaluated based on appearance, texture and aroma. For the evaluation, the scoring range from one to five was used, with the possibility of assigning half and quarter points. For each selected quality property, the coefficient of importance is determined in order to correct the given estimate by the multiplication of means. The coefficients of importance were chosen according to the influence of certain properties on the overall quality ( 4 for surface color, 3 for visual evaluated structure, 3 for palpatory evaluated firmness and 10 for olfactory evaluated odor), and their sum is 20. By combining individual scores, a complex indicator is obtained which represents the overall sensory quality and is expressed as a percent of the maximum possible quality (maximum possible quality is $100 \%$ ). By dividing this value with a set of coefficients of importance, a weighted average score is obtained, which also represents the total sensory quality of the tested samples of goat meat.

The scores are as follows:

- 1.00: very pronounced errors;

- 2.00: clearly expressed mistakes;

- 3.00: noticeable deviations;

- 4.00: minor deviations;

- 5.00: fully meets the quality requirements.

\subsection{Statistical analysis}

Data obtained in this study were analyzed using GraphPad Prism 6.0 software (GraphPad Software Inc., San Diego, CA, USA). All values are expressed as means and standard deviation. The differences between means were compared by oneway analysis of variance (one-way ANOVA) at the level of significance of $95 \%$. The significance of differences between mean values in groups was compared with Tukey's test at the level of significance of $95 \%$.

\section{Results}

\subsection{Live weight, chemical composition and $\mathrm{pH}$ value of meat}

Table 1 shows the live weights and the chemical composition and $\mathrm{pH}$ of the goat meat according to goat breed.

The Saanen goat was heavier, on average, than the Balkan and Alpine goat (Table 1). The mean contents of moisture, 
Table 1. Goat live weight and m. gluteus superficialis proximal composition and $\mathrm{pH}$ ( $n=40$ per breed).

\begin{tabular}{lrrrr}
\hline Parameter & Balkan goat & Alpine goat & Saanen goat & $P$ value (ANOVA) \\
\hline Live weight (kg) & $42.45 \pm 2.10^{\mathrm{a}}$ & $44.30 \pm 2.40^{\mathrm{b}}$ & $47.23 \pm 2.80^{\mathrm{c}}$ & 0.013 \\
Carcass weight (kg) & $19.08 \pm 0.11^{\mathrm{a}}$ & $19.99 \pm 0.08^{\mathrm{b}}$ & $21.31 \pm 0.19^{\mathrm{c}}$ & 0.018 \\
Moisture (\%) & $74.32 \pm 0.14^{\mathrm{a}}$ & $74.55 \pm 0.18^{\mathrm{b}}$ & $74.77 \pm 0.17^{\mathrm{c}}$ & 0.028 \\
Fat (\%) & $3.82 \pm 0.16^{\mathrm{a}}$ & $3.90 \pm 0.15^{\mathrm{b}}$ & $4.05 \pm 0.20^{\mathrm{c}}$ & 0.012 \\
Protein (\%) & $19.45 \pm 0.04^{\mathrm{a}}$ & $19.52 \pm 0.05^{\mathrm{b}}$ & $19.82 \pm 0.07^{\mathrm{c}}$ & 0.037 \\
Ash (\%) & $0.96 \pm 0.02^{\mathrm{a}}$ & $0.98 \pm 0.03^{\mathrm{b}}$ & $1.01 \pm 0.03^{\mathrm{c}}$ & 0.027 \\
pH after 24h & $5.68 \pm 0.04^{\mathrm{ns}}$ & $5.66 \pm 0.05^{\mathrm{ns}}$ & $5.65 \pm 0.03^{\mathrm{ns}}$ & 0.18 \\
\hline \multicolumn{5}{c}{} \\
ns No significant difference. \\
a, b, c Means within the same row with different superscripts differ significantly $(P<0.05)$.
\end{tabular}

Table 2. Fatty acid composition of fresh goat meat ( $\%$ of total fatty acids) (m. gluteus superficialis) $(n=40$ per breed).

\begin{tabular}{lrrrr}
\hline Parameter & Balkan goat & Alpine goat & Saanen goat & $P$ value (ANOVA) \\
\hline Capric acid (C10:0) & $0.51 \pm 0.04^{\mathrm{a}}$ & $0.60 \pm 0.05^{\mathrm{b}}$ & $0.64 \pm 0.04^{\mathrm{c}}$ & 0.011 \\
Lauric acid (C12:0) & $0.91 \pm 0.03^{\mathrm{a}}$ & $1.30 \pm 0.04^{\mathrm{b}}$ & $1.23 \pm 0.03^{\mathrm{c}}$ & 0.013 \\
Myristic acid (C14:0) & $10.02 \pm 0.05^{\mathrm{a}}$ & $10.31 \pm 0.05^{\mathrm{b}}$ & $10.52 \pm 0.06^{\mathrm{c}}$ & 0.02 \\
Pentadecanoic acid (C15:0) & $1.34 \pm 0.02^{\mathrm{a}}$ & $1.52 \pm 0.03^{\mathrm{b}}$ & $1.52 \pm 0.02^{\mathrm{c}}$ & 0.017 \\
Palmitic acid (C16:0) & $25.01 \pm 0.10^{\mathrm{a}}$ & $25.97 \pm 0.13^{\mathrm{b}}$ & $26.78 \pm 0.14^{\mathrm{c}}$ & 0.013 \\
Margaric acid (C17:0) & $0.19 \pm 0.01^{\mathrm{a}}$ & $0.23 \pm 0.02^{\mathrm{b}}$ & $0.29 \pm 0.01^{\mathrm{c}}$ & 0.014 \\
Stearic acid (C18:0) & $14.70 \pm 0.09^{\mathrm{a}}$ & $14.11 \pm 0.10^{\mathrm{b}}$ & $15.09 \pm 0.10^{\mathrm{a}}$ & 0.023 \\
Arachidic acid (C20:0) & $0.52 \pm 0.04^{\mathrm{a}}$ & $0.63 \pm 0.05^{\mathrm{b}}$ & $0.75 \pm 0.05^{\mathrm{c}}$ & 0.017 \\
Pentadecenoic acid (C15:1) & $0.18 \pm 0.02^{\mathrm{a}}$ & $0.14 \pm 0.01^{\mathrm{b}}$ & $0.10 \pm 0.01^{\mathrm{c}}$ & 0.015 \\
Palmitoleic acid (C16:1) & $2.30 \pm 0.03^{\mathrm{a}}$ & $2.42 \pm 0.02^{\mathrm{b}}$ & $2.13 \pm 0.02^{\mathrm{c}}$ & 0.011 \\
Eicosenoic acid (C20:1) & $0.36 \pm 0.02^{\mathrm{a}}$ & $0.23 \pm 0.02^{\mathrm{b}}$ & $0.12 \pm 0.01^{\mathrm{c}}$ & 0.018 \\
Heptadecenoic acid (C17:1nXc) & $0.24 \pm 0.02^{\mathrm{a}}$ & $0.16 \pm 0.01^{\mathrm{b}}$ & $0.10 \pm 0.01^{\mathrm{c}}$ & 0.012 \\
Elaidic acid (C18:1n9t) & $0.35 \pm 0.03^{\mathrm{a}}$ & $0.28 \pm 0.02^{\mathrm{b}}$ & $0.18 \pm 0.03^{\mathrm{c}}$ & 0.019 \\
Oleic acid (C18:1n9c) & $36.92 \pm 0.14^{\mathrm{a}}$ & $36.55 \pm 0.13^{\mathrm{a}}$ & $36.01 \pm 0.11^{\mathrm{b}}$ & 0.027 \\
Linolelaidic acid (C18:2n6t) & $0.47 \pm 0.03^{\mathrm{a}}$ & $0.40 \pm 0.04^{\mathrm{b}}$ & $0.30 \pm 0.05^{\mathrm{c}}$ & 0.016 \\
Linoleic acid (C18:2n6c) & $2.98 \pm 0.04^{\mathrm{a}}$ & $3.01 \pm 0.04^{\mathrm{b}}$ & $2.72 \pm 0.05^{\mathrm{c}}$ & 0.021 \\
Alpha-linolenic acid (C18:3n6) & $1.30 \pm 0.02^{\mathrm{a}}$ & $1.22 \pm 0.01^{\mathrm{a}}$ & $1.01 \pm 0.01^{\mathrm{b}}$ & 0.028 \\
\hline
\end{tabular}

a, b, c Means within the same row with different superscripts differ significantly $(P<0.05)$.

fat, protein and ash all differed between the goat breeds $(P<$ $0.05)$. However, the mean meat $\mathrm{pH}$ post rigor did not differ between the three goat breeds $(P>0.05)$.

\subsection{Fatty acid composition of goat meat}

The fatty acid composition of $m$. gluteus superficialis from Balkan goat, Alpine goat and Saanen goat is presented in Table 2. All determined fatty acids differed significantly between three examined breeds $(P<0.05)$ except oleic and alpha-linolenic acid which did not differ between Balkan and Alpine goat meats $(P>0.05)$ and stearic acid which did not differ between Balkan and Saanen goats $(P>0.05)$.

The sums and ratios of fatty acids in the goat meat is presented in Table 3. The ratio of unsaturated to saturated fatty acids in Balkan goats was 0.85, in Alpine goats it was 0.81, and in Saanen goats it was 0.82. Calculated ratios, as well as nutritional value, were significantly different between examined breeds $(P<0.05)$.

\subsection{Volatile substances in goat meat}

Table 4 shows the presence of specific volatile substances in $m$. gluteus superficialis in the three goat breeds, Balkan goat, Alpine goat and Saanen goat. The group of aldehydes was the most common groups of compounds identified in the analyzed goat meats. Among the aldehydes, $15.77 \pm 0.10 \mu \mathrm{g} \mathrm{kg}^{-1}$ of hexanal was detected in Balkan goat meat, $15.89 \pm 0.12 \mathrm{\mu g} \mathrm{kg}^{-1}$ in Alpine goat meat and $16.12 \pm 0.14 \mathrm{\mu g} \mathrm{kg}^{-1}$ in Saanen goat meat. The second most common group of compounds was the ketones. The predominant ketones in our fresh goat meat were 2-butanone and 2,3butanedione. Among the aromatic hydrocarbons we tested for, only methylbenzene was detected (Table 4). No phenols were detected in the goat meat examined. Also, only small 
Table 3. Indicators of the nutritional value and health benefits of fat determined based on an analysis of the fatty acid profile of goat meat $(n=40$ per breed).

\begin{tabular}{lrrrr}
\hline Indicator $^{1}$ & Balkan goat & Alpine goat & Saanen goat & $P$ value (ANOVA) \\
\hline$\Sigma$ SFA & $53.20 \pm 1.39$ & $54.67 \pm 0.79$ & $56.83 \pm 2.02$ & 0.061 \\
$\Sigma$ UFA & $45.10 \pm 1.75$ & $44.38 \pm 1.54$ & $46.67 \pm 1.44$ & 0.07 \\
$\Sigma$ MUFA & $40.35 \pm 1.94$ & $39.75 \pm 2.01$ & $38.64 \pm 1.43$ & 0.064 \\
$\Sigma$ PUFA & $4.75 \pm 1.04$ & $4.63 \pm 1.51$ & $4.03 \pm 1.39$ & 0.08 \\
UFA/SFA & $0.85 \pm 0.01^{\mathrm{a}}$ & $0.81 \pm 0.008^{\mathrm{b}}$ & $0.82 \pm 0.007^{\mathrm{c}}$ & 0.021 \\
MUFA/SFA & $0.76 \pm 0.02^{\mathrm{a}}$ & $0.73 \pm 0.03^{\mathrm{a}}$ & $0.68 \pm 0.01^{\mathrm{b}}$ & 0.023 \\
PUFA/SFA & $0.089 \pm 0.02^{\mathrm{a}}$ & $0.085 \pm 0.02^{\mathrm{b}}$ & $0.071 \pm 0.01^{\mathrm{c}}$ & 0.017 \\
DFA & $59.80 \pm 1.28^{\mathrm{a}}$ & $58.49 \pm 1.24^{\mathrm{a}}$ & $61.76 \pm 1.58^{\mathrm{b}}$ & 0.022 \\
OFA & $38.50 \pm 1.02^{\mathrm{a}}$ & $40.56 \pm 1.15^{\mathrm{b}}$ & $41.74 \pm 0.63^{\mathrm{b}}$ & 0.034 \\
EFA & $4.75 \pm 0.52^{\mathrm{a}}$ & $4.63 \pm 0.79^{\mathrm{b}}$ & $4.03 \pm 0.16^{\mathrm{c}}$ & 0.024 \\
Nutritional value* & $16.19 \pm 0.29^{\mathrm{a}}$ & $15.53 \pm 0.35^{\mathrm{b}}$ & $16.44 \pm 0.11^{\mathrm{c}}$ & 0.019 \\
\hline
\end{tabular}

SFA - Saturated fatty acid; UFA - Unsaturated fatty acid; MUFA - monounsaturated fatty acid; PUFA - polyunsaturated fatty acid; DFA - hypocholesterolemic fatty acid (UFA + C18:0); OFA - hypercholesterolemic fatty acid (SFA - C18:0); EFA - essential fatty acid (C18:2 + C18:3).

1 Calculations of all indicators in Table 6 were made according to Daszkiewicz and Mesinger (2018).

* Nutritional value was calculated according to the equation C18:0 + C18:1 / C16:0.

a, b, c Means within the same row with different superscripts differ significantly $(P<0.05)$

quantities of organic acids were present in the meat. Overall, Balkan goat meat contained fewer volatile substances than meat from Alpine and Saanen goats.

\subsection{Color of goat meat expressed in CIE L*a* $\mathrm{b}^{*}$ system}

Color parameters $\left(L^{*}, a^{*}, b^{*}\right)$ of goat leg meat derived from m. gluteus superficialis are presented in Table 5. A statistically significant difference $(P<0.05)$ occurred between the color of meat originating from Balkan and Saanen goats but not between Balkan and Alpine goats $(P>0.05)$ for all color parameters.

\subsection{Sensory evaluation of goat meat}

Comparisons of the overall sensory evaluation of meat from different goat breeds are shown in Table 6. No statistically significant difference was detected in the overall acceptability of Balkan and Alpine goat meats or of Alpine and Saanen goat meats $(P>0.05)$. There was a statistically significant difference $(P<0.05)$ in the acceptability of fresh Balkan and Saanen goat meats for the parameters of surface color and olfactory evaluated odor, as well as for average score. Balkan goat meat was more acceptable compared to the other two examined breeds.

\section{Discussion}

Meat quality can be affected by numerous factors: breed, gender, productivity, adaptation to stress, environment, management, nutrition, live weight and carcass weight at slaughter (McMillin, and Brock, 2005; Assan, 2015; Wattanachant, 2018). In the current study, the live weights of the three goat breeds, with Saanen goat being the heaviest of the three breeds, agree with the characteristics of the individual breeds given in previous studies (Dhanda et al., 2003; Memiši and Stanišić, 2014; Ivanović and Pavlović, 2015; Rojo-Rubio et al., 2016).

The percentages of moisture $(74.32 \%)$ and fat $(3.82 \%)$ in the Balkan goat meat in the current study were not in accordance with earlier studies on Bunte Deutsche Edelziege and Balkan goat meats (Ivanović et al., 2011), Serbian White goat and Balkan goat (Ivanović et al., 2014), or Balkan goats reared in a mountainous area (Ivanović et al., 2016). The protein and ash contents and $\mathrm{pH}$ of Balkan goat meat $(19.45 \%$, $0.96 \%$ and 5.68, respectively) were consistent with those in previous studies (Ivanovic et al., 2011, 2014, 2016).

Wattanachant et al. (2008) examined the quality characteristics of raw goat meat obtained from different ages and breeds of goats and proved significant differences between experimental groups. Numerous studies proved an influence of goat breed on meat quality, as well as different genotypes of the same breed (Dhanda et al., 1999; Peña et al., 2009; Brzostowski et al., 2008; Horcada et al., 2012; Özcan et al., 2015). Similar conclusions have been obtained in the current study, in which differences in meat quality between indigenous breeds and breeds improved by selection were examined.

In the current study, the most prevalent fatty acid in all examined breeds was oleic followed by palmitic, stearic and myristic acids. The highest content of oleic acid was determined in meat obtained from Balkan goat (36.92\%) followed by Alpine (36.55\%) and Saanen (36.01\%) goats. Regarding palmitic acid, the most prevalent content was in meat from Saanen goat $(26.78 \%)$ followed by Alpine $(25.79 \%)$ and Balkan $(25.01 \%)$ goats. The determined amounts of stearic 
Table 4. Volatile substances in fresh $m$. gluteus superficialis meat $\left(\mu \mathrm{g} \mathrm{kg}^{-1}\right)$ according to goat breed $(n=40$ per breed).

\begin{tabular}{|c|c|c|c|c|}
\hline Volatile substance $\left(\mu \mathrm{g} \mathrm{kg}^{-1}\right)$ & Balkan goat & Alpine goat & Saanen goat & $P$ value (ANOVA) \\
\hline \multicolumn{5}{|l|}{ Aldehydes } \\
\hline 3-Methylbutanal & $1.12 \pm 0.03^{\mathrm{a}}$ & $1.18 \pm 0.03^{b}$ & $1.26 \pm 0.04^{\mathrm{c}}$ & 0.017 \\
\hline Pentanal & $2.89 \pm 0.05^{\mathrm{a}}$ & $3.10 \pm 0.05^{\mathrm{b}}$ & $3.29 \pm 0.06^{\mathrm{c}}$ & 0.013 \\
\hline Hexanal & $15.77 \pm 0.10^{\mathrm{a}}$ & $15.89 \pm 0.12^{\mathrm{b}}$ & $16.12 \pm 0.14^{\mathrm{c}}$ & 0.016 \\
\hline Heptanal & $2.16 \pm 0.08^{\mathrm{a}}$ & $2.27 \pm 0.09^{b}$ & $2.43 \pm 0.10^{\mathrm{c}}$ & 0.019 \\
\hline Benzaldehyde & $0.17 \pm 0.02^{\mathrm{a}}$ & $0.23 \pm 0.02^{b}$ & $0.31 \pm 0.03^{\mathrm{c}}$ & 0.018 \\
\hline Octanal & $1.55 \pm 0.04^{\mathrm{a}}$ & $1.69 \pm 0.04^{\mathrm{b}}$ & $1.82 \pm 0.05^{\mathrm{c}}$ & 0.013 \\
\hline Nonanal & $2.85 \pm 0.07^{\mathrm{a}}$ & $2.99 \pm 0.07^{b}$ & $3.16 \pm 0.08^{\mathrm{c}}$ & 0.019 \\
\hline \multicolumn{5}{|l|}{ Ketones } \\
\hline 2,3-Butanedione & $0.22 \pm 0.03^{\mathrm{a}}$ & $0.27 \pm 0.03^{b}$ & $0.37 \pm 0.04^{\mathrm{c}}$ & 0.015 \\
\hline 2-Butanone & $3.40 \pm 0.08^{\mathrm{a}}$ & $3.52 \pm 0.09^{\mathrm{b}}$ & $3.59 \pm 0.10^{\mathrm{c}}$ & 0.02 \\
\hline 2-Pentanone & $0.08 \pm 0.01^{\mathrm{a}}$ & $0.13 \pm 0.01^{\mathrm{b}}$ & $0.19 \pm 0.02^{\mathrm{c}}$ & 0.019 \\
\hline 3-Hydroxy-2-butanone & $0.12 \pm 0.02^{\mathrm{a}}$ & $0.18 \pm 0.03^{b}$ & $0.26 \pm 0.03^{\mathrm{c}}$ & 0.023 \\
\hline 2-Heptanone & $0.22 \pm 0.03^{\mathrm{a}}$ & $0.29 \pm 0.03^{b}$ & $0.35 \pm 0.04^{\mathrm{c}}$ & 0.021 \\
\hline 2,3-Octanedione & $0.19 \pm 0.02^{\mathrm{a}}$ & $0.24 \pm 0.02^{b}$ & $0.32 \pm 0.03^{\mathrm{c}}$ & 0.017 \\
\hline \multicolumn{5}{|l|}{ Heterocyclic compounds } \\
\hline 2,6-Dimethylpyrazine & $0.07 \pm 0.02^{\mathrm{a}}$ & $0.11 \pm 0.03^{b}$ & $0.18 \pm 0.03^{c}$ & 0.016 \\
\hline \multicolumn{5}{|l|}{ Aromatic hydrocarbons } \\
\hline Methylbenzene & $0.09 \pm 0.03^{\mathrm{a}}$ & $0.14 \pm 0.03^{b}$ & $0.20 \pm 0.03^{\mathrm{c}}$ & 0.019 \\
\hline \multicolumn{5}{|l|}{ Phenols ${ }^{\text {nd }}$} \\
\hline \multicolumn{5}{|l|}{ Alcohols } \\
\hline 1-Penten-3-ol & $0.15 \pm 0.03^{\mathrm{a}}$ & $0.25 \pm 0.03^{\mathrm{b}}$ & $0.36 \pm 0.04^{\mathrm{c}}$ & 0.021 \\
\hline 2-Pentanol & $0.12 \pm 0.02^{\mathrm{a}}$ & $0.19 \pm 0.03^{b}$ & $0.27 \pm 0.03^{\mathrm{c}}$ & 0.019 \\
\hline 3-Methyl-1-butanol & $0.10 \pm 0.02^{\mathrm{a}}$ & $0.16 \pm 0.03^{\mathrm{b}}$ & $0.22 \pm 0.03^{\mathrm{c}}$ & 0.021 \\
\hline 1-Pentanol & $1.04 \pm 0.07^{\mathrm{a}}$ & $1.17 \pm 0.07^{\mathrm{b}}$ & $1.25 \pm 0.08^{\mathrm{c}}$ & 0.014 \\
\hline Furfurol & $0.10 \pm 0.03^{\mathrm{a}}$ & $0.18 \pm 0.03^{b}$ & $0.29 \pm 0.04^{\mathrm{c}}$ & 0.013 \\
\hline 1-Octen-3-ol & $0.99 \pm 0.03^{\mathrm{a}}$ & $1.11 \pm 0.04^{b}$ & $1.25 \pm 0.04^{\mathrm{c}}$ & 0.016 \\
\hline \multicolumn{5}{|l|}{ Organic acids } \\
\hline Acetic acid & $0.18 \pm 0.04^{\mathrm{a}}$ & $0.28 \pm 0.04^{b}$ & $0.37 \pm 0.05^{\mathrm{c}}$ & 0.017 \\
\hline Butanoic acid & $0.55 \pm 0.06^{\mathrm{a}}$ & $0.63 \pm 0.08^{b}$ & $0.74 \pm 0.10^{\mathrm{c}}$ & 0.021 \\
\hline 3-Methyl-butanoic acid & $0.06 \pm 0.02^{\mathrm{a}}$ & $0.14 \pm 0.03^{b}$ & $0.19 \pm 0.03^{\mathrm{c}}$ & 0.022 \\
\hline \multicolumn{5}{|l|}{ Alkanes } \\
\hline Hexane & $0.21 \pm 0.03^{\mathrm{a}}$ & $0.24 \pm 0.03^{\mathrm{b}}$ & $0.31 \pm 0.05^{\mathrm{c}}$ & 0,023 \\
\hline Heptane & $0.12 \pm 0.03^{\mathrm{a}}$ & $0.17 \pm 0.03^{b}$ & $0.23 \pm 0.03^{\mathrm{c}}$ & 0,027 \\
\hline Octane & $0.73 \pm 0.05^{\mathrm{a}}$ & $0.78 \pm 0.05^{\mathrm{b}}$ & $0.89 \pm 0.06^{\mathrm{c}}$ & 0.019 \\
\hline Nonane & $0.10 \pm 0.03^{\mathrm{a}}$ & $0.15 \pm 0.03^{b}$ & $0.20 \pm 0.04^{\mathrm{c}}$ & 0.021 \\
\hline \multicolumn{5}{|l|}{ Alkenes } \\
\hline 1-Octene & $0.12 \pm 0.03^{\mathrm{a}}$ & $0.19 \pm 0.04^{b}$ & $0.28 \pm 0.04^{\mathrm{c}}$ & 0.017 \\
\hline
\end{tabular}

nd Not detected.

a,b,c Means within the same row with different superscripts differ significantly $(P<0.05)$. 
Table 5. Color of fresh goat meat following the CIE $\mathrm{L}^{*} \mathrm{a}^{*} \mathrm{~b} *$ system $(n=40$ per breed).

\begin{tabular}{lrrr}
\hline Parameter & $\mathrm{L}^{*}$ & $\mathrm{a}^{*}$ & $\mathrm{~b}^{*}$ \\
\hline Balkan goat & $31.66 \pm 1.11^{\mathrm{a}}$ & $18.43 \pm 0.65^{\mathrm{a}}$ & $3.88 \pm 0.30^{\mathrm{a}}$ \\
Alpine goat & $31.99 \pm 1.32^{\mathrm{a}, \mathrm{b}}$ & $18.63 \pm 0.72^{\mathrm{a}, \mathrm{b}}$ & $3.98 \pm 0.40^{\mathrm{a}, \mathrm{b}}$ \\
Saanen goat & $32.41 \pm 1.47^{\mathrm{b}}$ & $18.87 \pm 0.83^{\mathrm{b}}$ & $4.13 \pm 0.52^{\mathrm{b}}$ \\
$P$ value (ANOVA) & 0.031 & 0.029 & $\leq 0.033$ \\
\hline $\mathrm{L}^{*}-$ lightness; $\mathrm{a}^{*}-$ redness; $\mathrm{b}^{*}-$ yellowness. & & \\
$\mathrm{a}, \mathrm{b}$ Means within the same column with different superscripts differ significantly $(P<0.05)$.
\end{tabular}

Table 6. Sensory evaluation of goat meat.

\begin{tabular}{|c|c|c|c|c|c|c|}
\hline & \multicolumn{4}{|c|}{ Attributes } & \multirow{5}{*}{$\begin{array}{l}\text { Percentage of maximal } \\
\text { possible quality }\end{array}$} & \multirow{5}{*}{$\begin{array}{l}\text { Weighted } \\
\text { average } \\
100 / 20\end{array}$} \\
\hline & Appearance & \multicolumn{2}{|c|}{ Texture } & Flavor & & \\
\hline & $\begin{array}{l}\text { Surface } \\
\text { color }\end{array}$ & $\begin{array}{l}\text { Visually } \\
\text { evaluated } \\
\text { structure }\end{array}$ & $\begin{array}{l}\text { Palpatory } \\
\text { evaluated } \\
\text { firmness }\end{array}$ & $\begin{array}{l}\text { Olfactory } \\
\text { evaluated } \\
\text { odor }\end{array}$ & & \\
\hline & \multicolumn{4}{|c|}{ Coefficient of importance } & & \\
\hline & 4 & 3 & 3 & 10 & & \\
\hline Balkan goat & $18.60 \pm 0.28^{\mathrm{a}}$ & $14.70 \pm 0.25$ & $13.80 \pm 0.23$ & $47.50 \pm 0.32^{\mathrm{a}}$ & 94.60 & $4.73^{\mathrm{a}}$ \\
\hline Alpine goat & $19.00 \pm 0.25^{\mathrm{a}, \mathrm{b}}$ & $13.80 \pm 0.18$ & $13.95 \pm 0.18$ & $46.00 \pm 0.13^{\mathrm{a}, \mathrm{b}}$ & 92.75 & $4.64^{\mathrm{a}, \mathrm{b}}$ \\
\hline Saanen goat & $18.40 \pm 0.28^{\mathrm{b}}$ & $13.80 \pm 0.16$ & $13.20 \pm 0.39$ & $44.60 \pm 0.20^{\mathrm{b}}$ & 90.00 & $4.50^{\mathrm{b}}$ \\
\hline$P$ value (ANOVA) & 0.019 & 0.056 & 0.067 & 0.024 & 0.07 & 0.031 \\
\hline
\end{tabular}

acid were $15.09 \%, 14.70 \%$ and $14.11 \%$ for Saanen, Balkan and Alpine goats, respectively. The concentration of linoleic acid, an essential fatty acid, was the highest in the gluteus muscles of Alpine goat and the lowest in the Saanen goat.

These results were not the same as in earlier research (Ivanović et al., 2012, 2014) as the breed and method of raising goats were different. During 2012, the fatty acid composition of Bunte Deutsche Edelziege goats which were 3 and 6 years old was investigated. In 2014, the difference in meat quality of Serbian White and Balkan goats, both grown in mountainous areas, was examined (Ivanović et al., 2014). A statistically significant difference in fatty acids was found between these two breeds. In the current study, Balkan goat meat quality parameters were in agreement with the results obtained in previous studies of Balkan goats reared in a mountainous region (Ivanović et al., 2016).

The breed is a source of variation for fat deposition, total intramuscular fat content and fatty acid profile of goat meat (Ding et al., 2010; Horcada et al., 2012; Assan, 2015; Wattanachant, 2018). Dhanda et al. (1999) have shown a 10 to $13 \%$ difference in total fat content in different goat breeds with no significant difference in carcass weight. The influence of breed on the fatty acid profile of adipose tissue has been reported (Dhanda et al., 2003). Özcan et al. (2015) have shown the differences in levels of some fatty acids but not in the ratios of polyunsaturated fatty acids (PUFAs) to saturated fatty acids (PUFAs / SFAs) or n-6/n-3. In the current study, all determined fatty acids $(P<0.05)$ varied significantly, which points to the impact of breed on the fatty acid profile of meat due to large differences between native breeds and breeds improved by selection. It is important to point out that breed and genotype can not be observed as a single deciding factor for the fatty acid profile of meat, but they are associated with other factors like nutrition, management, age, gender etc. (Wattanachant, 2018).

Among the fatty acids, not all have the same effect on human health. Lauric (C12:0), myristic (C14:0) and palmitic (C16:0) acids are thought to exert atherogenic effects which can thus increase the concentration of low-density lipoprotein (LDL) cholesterol in blood (Howell et al, 1997). Myristic acid has the most adverse effect on the cardiovascular system, which is 4 times more pronounced compared to lauric and palmitic acids (Hegsted et al., 1959). On the other hand, stearic acid is considered to be neutral.

In the current study, the content of lauric, myristic and palmitic acids was the lowest in Balkan goat meat. The highest content of stearic acid was measured in Saanen goat meat, but it was not significantly higher compared to Balkan goat. 
Thus, the significantly lower content of myristic, palmitic and lauric acids along with determined levels of stearic acid observed in this study point to the greater health benefits of Balkan goat meat over meat obtained from the other two examined breeds.

Regarding overall fatty acids, $m$. gluteus superficialis of Saanen goat had the highest content of total SFAs and UFAs compared to the other examined goats, but, at the same time, Balkan goat meat was determined to have the highest content of PUFAs. Balkan goat meat had more OFAs, but essential fatty acids (EFAs) were more prominent in Alpine goat meat. Ratios of PUFAs and SFAs are recommended to be higher than 0.4 (Wood et al., 2008), and in this trial they were higher than the recommended level for all examined breeds. Calculated nutritional value was the highest for Saanen goat meat. Calculated ratios were in-line with findings of some other authors (Peña et al., 2009; Solaiman et al., 2011). Results presented here are not in-line with Özcan et al. (2015), which may be the consequence of different experimental approaches, as well as different breeds and ages of goats included in the trial.

High amounts of unsaturated and particularly polyunsaturated fatty acids are thought to enhance the nutritional and health-promoting value of meat. However, unsaturated fatty acids are more susceptible to oxidation and thus can have an influence on meat sensory characteristics and, furthermore, can cause toxic compound synthesis (Daszkiewicz and Mesinger, 2018).

The most common group of compounds identified in meat from all three breeds was aldehyde, with hexanal being predominant among the volatiles (up to $16.12 \mu \mathrm{g} \mathrm{kg}^{-1}$ ). Other volatile compounds were determined in the following order: ketones $>$ alcohols $>$ alkanes $>$ organic acids $>$ alkenes $>$ aromatic hydrocarbons $>$ heterocyclic compounds.

Aldehydes in general are major sources of volatile fractions obtained from domestic ruminant meat (Vasta and Priolo, 2006; Villalobos-Delgado et al., 2014; Ivanović et al., 2016). Within the group, linear aldehydes that are produced in fat oxidative degradation were detected with the exception of benzaldehyde (Belitz and Grosch, 1987; Ripoll et al., 2019). Hexanal, predominant in the examined samples, is mainly derived from linoleic and arachidonic acids (Martin et al., 2002). Measured concentrations of those fatty acids in goat meat samples differed significantly between breeds, as well as hexanal concentrations. Aldehydes have a low aroma threshold and an intense and specific aroma, which can make them important contributors to the aromatic meat profile (Madruga et al., 2009). They have a greasy, green grass and apple flavor, especially hexanal, which is described as having a delicate and grassy fragrance related to the smell of newly mown grass but also possibly having the bad smell of green beans and a rancid aroma when present in high concentrations (Frank et al., 2017; Chen et al., 2019). Aldehyde content is determined by fatty acid and protein content in meat and varies among breeds. That fact points out the im- pact of breed and genotype on the volatile profile of meat. The determined aldehyde levels in Balkan goat meat were in agreement with the results obtained in previous studies of meat from Balkan goats reared in a mountainous region (Ivanović et al., 2016).

Aldehydes are believed to form as a result of lipid oxidation and protein degradation, while ketones generally correlate with the type of diet (Ivanović et al., 2016). Among ketones, the highest determined concentration had 2-butanone. 2-Ketones are significant contributors to meat aroma and flavor because they have a peculiar aroma that is described as having ethereal, buttery and spicy notes or blue cheese notes (Creuly et al., 1992; Lecanu et al., 2002). Determined levels of 2,3-octanedione fit with the suggestion that it occurs in higher amounts in meat from grass-fed animals (Vasta and Priolo, 2006). Sivadier et al. (2010) suggest that 2,3octanedione may serve as a biomarker confirming that meat originates from animals feeding in pastures (Kosowska et al., 2017).

Alcohols are formed as products of the oxidation of lipids or their oxidation products, like hexanal or heptanal (Kosowska et al., 2017). Furthermore, alcohol formation is attributed to microorganisms' activity, like 3-methyl 1butanol being formed in the degradation of amino acids (Muriel et al., 2004). Alcohols have herbaceous, woody and fatty notes (Lorenzo et al., 2013). The determined levels of aldehydes in the current study that can be precursors for alcohol synthesis were significantly different between breeds, as well as levels of alcohols, which supports the breed's impact on volatile compounds in meat.

Only small amounts of organic acids in meat were detected in the current study, although they are responsible for the distinctive taste of goat meat. Organic acids with less than six carbon atoms (short chain acids) are considered significant contributors to the volatile profile of meat because of their specific odors - vinegar, cheese or cucumber - as well as their low threshold values (Lorenzo et al., 2013). A pungent and sour odor note is attributed to acetic acid (Kosowska et al., 2017).

From the group of alkanes, octane was the most prevalent followed by hexane. Except for octane, the determined amount of alkanes was at the level of $0.2 \mu \mathrm{gg}^{-1}$. It can be seen that alkanes did not have a significant influence on goat meat taste and aroma due to their high threshold values (Drumm and Spanier, 1991).

The presence of aromatic hydrocarbons, alkanes and heterocyclic compounds was marginal, but they may have synergistic effects with other compounds in the formation of meat aroma and taste.

The color results obtained differed from our previous investigations regarding Balkan and Bunte Deutsche Edelziege goats (Ivanović et al., 2011) and goat meat quality (Ivanović et al., 2014). On average, meat from Saanen goat was lighter compared to the other two examined breeds. Furthermore, the same breed had higher redness and yellowness param- 
eters compared to the other breeds and significantly higher compared to Balkan goat $(P<0.05)$.

Meat color may be affected by numerous factors, including type/breed, structure and the ratio of intramuscular fat (Ivanović and Pavlović, 2015), which may be the cause of color differences in the current study. The color of meat may correlate with the content of intramuscular fat. In the current study, the intramuscular fat content and fatty acid profile differed significantly between breeds. Balkan goat had the lowest total fat content, followed by Alpine and Saanen goats. In accordance with that, color parameters were the lowest for Balkan goat and significantly lower compared to the other two examined breeds. Although there were not significant differences between Alpine and Saanen goat meats for $\mathrm{L}^{*}$, $a^{*}$ and $b^{*}$ values, they differed in the same order for total fat content measured, which may be the cause of color differences between the examined breeds. Similar to those findings, Peña et al. (2009) and Dhanda et al. (2003) proved the influence of breed on meat color. On the other hand, Madruga et al. (2008) show significant differences $(P<0.05)$ in the values for the $\mathrm{a}^{*}$ parameter of meat color between breeds but not for the $L^{*}$ and $b^{*}$ parameters.

Balkan goat meat was more sensorially acceptable than Saanen goat meat overall. The results of the current study have slight differences in the sensory evaluation of the color and the odor of the examined samples, which are both factors that affect the overall acceptability of meat. That is consistent with the findings of other authors (Peña et al., 2009; Ding et al., 2010). However, sensory evaluation is very difficult to compare between studies as the meat evaluated derives from goats reared in completely different conditions (climate, feed and growing conditions). Furthermore, different techniques in sensory evaluation are applied.

\section{Conclusions}

In comparing the results of analyzed meat quality parameters of meat from Balkan, Alpine and Saanen goats, significant differences were measured in moisture, total fats, proteins, ash, instrumentally defined color and the sensory evaluation of meat. Furthermore, differences were determined in the fatty acids and volatile profile of meat. Alpha-linolenic (n-3 FA) and linolelaidic acids were found in higher percentages in Balkan goat meat, while Alpine goat meat contained the highest amounts of linoleic acid among the three goat breeds. Balkan goat meat contained fewer volatile substances than meat from Alpine and Saanen goats. The overall sensory acceptability was ranked the best for Balkan goat meat. From the presented results, it can be concluded that from meat obtained from indigenous breeds, the Balkan goat had favorable nutritional and health benefits, particularly if the consumer's demand is lean meat.

The results obtained in this study suggest breed has an impact on the quality of goat meat and, therefore, potentially on the quality of goat meat products. However, the current study is not without limitations. First of all, some fatty acids and volatile compounds were not identified, indicating that further research is required. Furthermore, the evaluation of fresh meat was conducted, which does not reflect the conditions in which goat meat is routinely processed; thus, studies should be carried out on such meat products as well. Finally, it would have been helpful to carry out studies which include several different breeds.

Data availability. The underlying research data can be obtained from the corresponding author, who can be reached by mail: majaspavlovic@gmail.com.

Author contributions. SI and IP designed the experiment, AT carried out the analyses, JJ worked on writing the original draft of the paper, MP conducted the statistical analyses and prepared the paper with contributions from all co-authors, and MŽB provided the financial support for the project.

Competing interests. The authors declare that they have no conflict of interest.

Acknowledgements. The research was done within project TR 31053, "Implementation of new biotechnological solutions in breeding of cattle, sheep and goats for the purpose of obtaining biologically valuable and safe food", funded by the Ministry of Education and Science of the Republic of Serbia.

Financial support. This research has been supported by the Ministry of Education and Science of the Republic of Serbia.

Review statement. This paper was edited by Steffen Maak and reviewed by two anonymous referees.

\section{References}

Assan, N.: Some factors influencing dressing per-centage in goat meat production, Sci. J. Rev., 4, 156-164, 2015.

Association of Official Analytical Chemists (AOAC 996.06): Fat (total, saturated, and unsaturated) in food, hydrolytic extraction gas chromatographic method, in: Official Methods of Analysis, AOAC, Arlington, VA, USA, 2001.

Banskalieva, V., Sahlu, T.A, and Goetsch, A. L.: Fatty acid composition of goat muscles and fat depots: a review, Small Ruminant Res., 37, 255-268, 2000.

Belitz, H. D. and Grosch, W.: Lipids, in: Food Chemistry, Springer Verlag, Berlin, 128-200, 1987.

Brzostowski, H., Niżnikowski, R., and Tański, Z.: Quality of goat meat from purebred French Alpine kids and Boer crossbreeds, Arch. Anim. Breed, 51, 381-388, 2008. 
Chen, G., Su, Y., He, L., Wu, H., and Shui, S.: Analysis of volatile compounds in pork from four different pig breeds using headspace solid-phase micro-extraction/gas chromatographymass spectrometry, Food Sci. Nutr., 7, 1261-1273, 2019.

CIE Colorimetry: CIE No. 15.2, 2nd edn., Central Bureau of the Commission Internationale de L'Ectarge, Vienna, 1986.

Costa, R. G., Cartaxo, F. Q., Santos, N. M., and Queiroga, R. C. R. E.: Goat and sheep meat: fatty acids composition and sensorial characteristics, Rev. bras. saúde prod. anim., 9, 497-506, 2008.

Creuly, C., Laroche, C., and Gros, J. B.: Bioconversion of fatty acids into methyl ketones by spores of Penicillium roquefortii in a water organic solvent, two phase system, Enzyme Microb. Tech., 14, 669-678, 1992.

Čobanović, N., Jamnikar-Ciglečenki, U., Kirbiš, A., Križman, M., Štukelj, M., and Karabasil, N.: Impact of various housing conditions on the occurrence of pathological lesions in slaughtered pigs, Vet. Glas., 73, 17-29, 2019.

Daszkiewicz, T. and Mesinger, D.: Fatty acid profile of meat (Longissimus lumborum) from female roe deer (Capreolus capreolus L.) and red deer (Cervus elaphus L.), Int. J. Food Prop., 21, 2276-2282, 2018.

Dhanda, J. S., Taylor, D. G., Murray, P. J., and McCosker, J. E.: The influence of goat genotype on the production of Capretto and Chevon carcasses. 1. Growth and carcass characteristics, Meat Sci., 52, 355-361, 1999.

Dhanda, J. S., Taylor, D. G., Murray, P. J., Pegg, R. B., and Shand, P. J.: Goat meat production: Present status and future possibility, Asian Austral. J. Anim., 16, 1842-1852, 2003.

Ding, W., Kou, L., Cao, B., and Wei, Y.: Meat quality parameters of descendants by grading hybridization of Boer goat and Guanzhong dairy goat, Meat Sci., 84, 323-328, 2010.

Drumm, T. D. and Spanier, A. M.: Changes in the content of lipid autoxidation and sulfur-containing compounds in cooked beef during storage, J. Agr. Food Chem., 39, 336-343, 1991.

Eurostat: Animal populations by NUTS 2 regions, available at: https://ec.europa.eu/eurostat/databrowser/view/tgs00045/ default/table?lang=en, last access: 16 April 2020.

FAO: Livestock primary production (goat, producing animals), available at: http://www.fao.org/faostat/en/\#data/QA, last access: 16 April 2020.

Frank, D., Raeside, M., Behrendt, R., Krishnamurthy, R., Piyasiri, U., Rose, G., Watkins, P., and Warner, R.: An integrated sensory, consumer and olfactometry study evaluating the effects of rearing system and diet on flavor characteristics of Australian lamb, Anim. Prod. Sci., 57, 347-362, 2017.

Givens, D. I., Kliem, K. E., and Gibbs, R. A.: The role of meat as a source of n-3 polyunsaturated fatty acids in the human diet, Meat Sci., 74, 209-218, 2006.

Hegsted, D. M., Gotsis, A., Stare, F. J., and Worcester, J.: Interrelations between the kind and amount of dietary fat and dietary cholesterol in experimental hypercholesterolemia, Am. J. Clin. Nutr., 7, 5-12, 1959.

Horcada, A., Ripoll, G., Alcalde, M. J., Sañudo, C., Teixeira, A., and Panea, B.: Fatty acid profile of three adipose depots in seven Spanish breeds of suckling kids, Meat Sci., 92, 89-96, 2012.

Howell, W. H., McNamara, D. J., Tosca, M. A., Smith, B. T., and Gaines, J. A.: Plasma lipid and lipoprotein responses to dietary fat and cholesterol: a meta analysis, Am. J. Clin. Nutr., 65, 1747 $-1764,1997$.
ISO 937:1992: Meat and meat products - Determination of nitrogen content (Reference method), International Organization for Standardization, Geneva, Switzerland, 1992.

ISO 936:1999: Meat and meat products - Determination of total ash, International Organization for Standardization, Geneva, Switzerland, 1999.

ISO 1442:1998: Meat and meat products - Determination of moisture content (Reference method), International Organization for Standardization, Geneva, Switzerland, 1998.

ISO 1443:1992: Meat and meat products - Determination of total fat content, International Organization for Standardization, Geneva, Switzerland, 1992.

ISO 15303:2001: Animal and vegetable fats and oils - Detection and identification of a volatile organic contaminant by GC/MS, 2001.

ISO 2917:2004: Meat and meat products - Measurement of $\mathrm{pH} 75$ (Reference method), International Organization for Standardization, Geneva, Switzerland, 2004.

ISO 8586, 2012, 2015: Sensory Analysis - Methodology - Initiation and Training of Assessors in the Detection and Recognation of Odours, International Organization for Standardization, Geneva, Switzerland, 2015.

Ivanović, S. and Pavlović, I.: Meso koza bezbedna namirnica [in Serbian], Naučni institut za veterinarstvo Srbije, Belgrade, Serbia, 2015.

Ivanović, S., Popov-Raljić, J., Baltić, Ž.M., Žujovic, M., Tomić, Z., Lilić, S., and Pavlović, I.: Chemical and sensory characteristics of bunte deutsche edelziege and balkan goat meat, Afr. J. Biotechnol., 10, 18433-18439, 2011.

Ivanović, S., Stojanović, Z., Pisinov, B., Nešić, K., Pihler, I., Maksimović, N., and Stanišić, N.: Influence of slaughter age on meat quality of goat, in: Proceedings of the 15th International Feed Technology Symposium "Feed-to-food"/cost feed for health joint Workshop, 3-5 October 2012, Novi Sad, Serbia, 284-289, 2012.

Ivanović, S., Stojanović, Z., Nešić, K., Pisinov, B., Baltić, Ž.M., Popov-Raljić, J., and Đurić, J.: Effect of goat breed on the meat quality, Hem. Ind., 68, 801-807, 2014.

Ivanović, S., Nešić, K., Pisinov, B., and Pavlović, I.: The impact of diet on the quality of fresh meat and smoked ham in goat, Small Ruminant Res., 138, 53-59, 2016.

Kosowska, M., Majcher, M. and Fortuna, T.: Volatile compounds in meat and meat products, Food Sci. Technol.-Brazil, 37, 1-7, 2017.

Lakušić, D. and Cetković, A.: Biodiversity of Stara Planina in Serbia, in: Report of the Project Trans Boundary Cooperation Through the Management of Shared Natural Resources: Promotion of Networks and Exchanges in the Countries of SouthEastern Europe, The Regional Environmental Center for Central and Eastern Europe, Belgrade, Serbia, 2007.

Lecanu, L., Ducruet, V., Jouquand, C., Gratadoux, J. J., and Feigenbaum, A.: Optimization of headspace solidphase microextraction (SPME) for the odor analysis of surface-ripened cheese, J. Agr. Food Chem., 50, 3810-3817, 2002.

Lee, J. H., Kouakou, B., and Kannan, G.: Chemical composition and quality characteristics of chevon from goats fed three different post-weaning diets, Small Ruminant Res., 75, 177-184, 2008.

Likens, S. T. and Nickerson, G. B.: Detection of certain hop oil constituents in brewing products, in: Proceedings of the Annual 
meeting - American Society of Brewing Chemists, J. Am. Soc. Brew. Chem., 22, 5-13, 1964.

Lorenzo, J., Carballo, J., and Franco, D.: Effect of the Inclusion of Chestnut in the Finishing Diet on Volatile Compounds of DryCured Ham from Celta Pig Breed, J. Integr. Agric., 12, 20022012, 2013.

Madruga, M., Elmore, J., Dodson, A., and Mottram, D.: Volatile flavour profile of goat meat extracted by three widely used techniques, Food Chem., 115, 1081-1087, 2009.

Madruga, M. S., Torres, T. S., Carvalho, F. F., Queiroga, R. C., Narain, N., and Garruti, D.: Meat quality of Moxotó and Canindé goats as affected by two levles of feeding, Meat Sci., 80, 10191023, 2008.

Martin, L., Timon, L. M., Petron, J. M., Ventanas, J., and Antequera, T.: Evolution of volatile aldehydes in Iberian ham matured under different processing condition, Meat Sci., 54, 323-327, 2002.

McMillin, K. W. and Brock, A. P.: Production practices and processing for value-added goat meat, J. Anim. Sci., 83, E57-E68, 2005.

Memiši, N. and Stanišić, N.: Influence of different growing conditions on production, milk composition and body condition score for alpina goat breed, Biotechnology in Animal Husbandry, 30, 635-646, 2014.

Muriel, E., Antequera, T., Petrón, M. J., Andrés, A. I., Ruiz, J.: Volatile compounds in Iberian dry-cured loin, Meat Sci., 68, 391-400, 2004.

National Research Council: Nutrient Requirements of Small Ruminants: Sheep, Goats, Cervids, and New World Camelids, The National Academies Press, Washington, DC, 2007.

Özcan, M., Demirel, G., Yakan, A., Ekiz, B., Tõlü, C., and Savaş, T.: Genotype, production system and sex effects on fatty acid composition of meat from goat kids, Anim. Sci. J., 86, 200-206, 2015.

Peña, F., Bonvillani, A., Freire, B., Juárez, M., Perea, J., and Gómez, G.: Effects of genotype and slaughter weight on the meat quality of Criollo Cordobes and Anglonubian kids produced under extensive feeding conditions, Meat Sci., 83, 417-422, 2009.

Ripoll, G., de Guía Córdoba, M., Alcalde, M. J., Martín, A., Argüello, A., Casquete, R., and Panea, B.: Volatile organic compounds and consumer preference for meat from suckling goat kids raised with natural or replacers milk, Ital. J. Anim. Sci., 18, 1259-1270, 2019.

Rojo-Rubio, R. , Kholif, A. E., Salem, A. Z. M., Mendoza, G. D., Elghandour, M. M. M. Y., Vazquez-Armijo J. F., and Lee-Rangel H.: Lactation curves and body weight changes of Alpine, Saanen and Anglo-Nubian goats as well as pre-weaning growth of their kids, J. Appl. Anim. Res., 44, 331-337, 2016.

Silva, T. M., Oliveira, R. L., Barbosa, L. P., GarcezNeto, A. F., Bagaldo, A. R., Duarte Lanna, D. P., Alves da Silva, M. C., and Brito de Jesus, I.: Preliminary Study on Meat Quality of Goats Fed Levels of Licury Oil in the Diet, Asian Austral. J. Anim., 24, 1112-1119, 2011.
Sivadier, G., Ratel, J., and Engel, E.: Persistence of pasture feeding volatile biomarkers in lamb fats, Food Chem., 118, 418-425, 2010.

Solaiman, S., Kerth, C., Willian, K., Min, B. R., Shoemaker, C., Jones, W., and Bransby, D.: Growth performance, carcass characteristics and meat quality of boer-cross wether and buck goats grazing marshall ryegrass, Asian Austral. J. Anim., 24, 351-357, 2011.

Statistical Office Of The Republic Of Serbia: Statistical Database, available at: https://data.stat.gov.rs/Home/Result/ 130202010205 ?languageCode $=$ sr-Cyrl (last access: 16 April 2020), 2019.

Stanišić, N., Žujović, M., Tomić, Z., Maksimović, N., Bijelić, Z., Ivanović, S., and Memiši, N.: The effects of crossing Balkan and Saanen goat breeds on carcass traits and certain quality parameters of kid meat, Ann. Anim. Sci., 12, 53-62, 2012.

Stevanović, V.: Flora of Serbia (second edn.), Serbian Academy of Sciences and Arts, Belgrade, Serbia, 2012.

Tefiel, H., Ata, N., Chahbar, M., Benyarou, M., Fantazi, K., Yilmaz, O., and Gaouar, S. B. S.: Genetic characterization of four Algerian goat breeds assessed by microsatellite markers, Small Ruminant Res., 160, 65-71, 2018.

Toplu, H. D. O., Goksov, E. O., Nazligul, A., and Kahraman, T.: Meat quality characteristics of Turkish indigenous Hair goat kids reared under traditional extensive production system: effects of slaughter age and gender, Trop. Anim. Health Pro., 45, 1297 1304, 2013.

Vasta, V. and Priolo, A.: Ruminant fat volatiles as affected by diet, Meat Sci., 73, 218-228, 2006.

Villalobos-Delgado, H. L., Caro, I., Blanco, C., Morán, L., Prieto, N., Bodas, R., Giráldez, F. J., and Mateo, J.: Quality characteristics of a dry-cured lamb leg as affected by tumbling after drysalting and processing time, Meat Sci., 97, 115-122, 2014.

Wattanachant, S., Sornprasitt, T., and Polpara, Y.: Quality characteristics of raw and canned goat meat in water, brine, oil and Thai curry during storage, Songklanakarin J. Sci. Technol., 30, 41-50, 2008.

Wattanachant, C.: Goat meat: Some factors affecting fat deposition and fatty acid composition, Songklanakarin J. Sci. Technol., 40, 1152-1157, 2018.

Wood, J. D., Enser, M., Fisher, A. V., Nute, G. R., Sheard, P. R., Richardson, R. I., Hughes, S. I., and Whittington, F. M.: Fat deposition, fatty acid composition and meat quality: A review, Meat Sci., 78, 343-358, 2008.

Žujović, M., Stanišić, N., Memiši, N., and Mlekara, A. D.: Autochthonous Balkan goat breed-composition and traits of kid carcass, Biotech. Anim. Husbandry, 25, 411-420, 2009.

Žujović, M., Memiši, N., and Ivanović, S.: Present status, possibilities and perspective of development of goat production in Republic of Serbia, Biotech. Anim. Husbandry, 27, 431-443, 2011. 